\title{
Productivity and Relationships with Life Happiness, and Cross-Cultural Dimensions: A Multinational Quantitative Analysis
}

\author{
Peter C. Ogonowski, Ph.D. \\ Economics Division, CDM Smith, Orlando, United States \\ Email: pogonowski@capellauniversity.edu
}

\begin{abstract}
This study evaluated the relationships between national productivity, life happiness, and cultural dimensions in a global framework. The purpose of the study originated from the continued quest for fuller explanations behind persistent differences in international productivity performance, together with the recent worrisome productivity growth deceleration observed in multiple of the world's key economies. Based on applying multivariate regression analysis and hypotheses testing, it was found that the study's omnibus null hypothesis, all four main null hypotheses were rejected in favor of their alternative hypotheses. The results suggested that globalization-impacted businesses seeking to optimize their productivity performance could capitalize on their human factor allocations drawing on the energy of life happiness and certain cultural dimensions - particularly individualism and power distance, either singularly or in combination with other explanatory variables. Implications and further research recommendations for enhancing the understanding of and improving productivity outcomes in a globalizing economy were also provided.
\end{abstract}

Keywords: Productivity, life happiness, cultural dimensions, international economics, globalization

\section{Introduction}

Productivity is a crucial driver of business and economic performance. It impacts unit labor costs and revenues and, consequently, profits and shareholder value generation. Changes in productivity largely affect what businesses can afford to pay their workers in terms of compensation, which influences living standards and impacts consumer expenditures, and those, in turn, also determine business revenues and profits, and overall economic activity (van Ark and McGuckin, 1999). As one Nobel Prize-winning economist posited "Productivity isn't everything, but in the long run it is almost everything" (Krugman, 1997, p. 11; Nobel Prize, 2016). As economic and business data have improved, interest in performance measurement has increased, and new insights regarding both the history and future of productivity continue to emerge (Dey-Chowdhury, 2008; Inklaar, Timmer, and van Ark, 2007; J. Smith, 2003; Syverson, 2011; van Ark, 2005; van Ark and McGuckin, 1999).

Productivity growth has exhibited some worrying trends, particularly over the last decade. After relatively strong growth for most of the 20th century, especially during the post-World War II quarter century, productivity in the United States (U.S.), and other mostly industrialized nations, decelerated or stagnated with relatively low growth rates, which continues in the post-Great Recession era, all with detrimental impacts to business growth performance and living standards (Bergeaud, Cette, and Lecat, 2014; Brynjolfsson, 1993; Bureau of Labor Statistics, 2012a, 2016a, 2016b; Clark, 2016; Conference Board, 2015a; Duarte and Restuccia, 2006, 2010; Eichengreen, 2015; Field, 2007; Galson and Kamarck, 2015; Gordon, 2012, 2015, 2016; Griliches, 1988; Lagarde, 2015; Maddison, 2001; National Bureau of Economic Research, 2010; Nolan, 2014; Organization for Economic Co-operation and Development, 2026a; Sargent, 2013; Siegel, 2015; Triplett, 1999; van Ark, 2005, 2010; Weller and Odum, 2015).

This productivity conundrum is not fully explained by the key theories of productivity, such as Solow's (1957) technological change-oriented theory or its augmented version by Mankiw, Romer, and Weil (1992), or the Heckscher-Ohlin resource endowments theory and international trade model (Ohlin, 1957). Consequently, additional answers are sought in the human factors affecting productivity. More specifically, it is hypothesized in this study that life happiness and cultural dimensions of the workforce could add to the understanding of productivity drivers. By generating useful insights for business and 
policy decision-makers, as well as academics, this understanding may aid in bridging the gap between theory and practice.

\section{$2 \quad$ Study Background}

This section summarizes the related background based on the key literature review findings.

\subsection{Productivity}

Productivity has been a subject of academic and practitioner inquiries for more than two centuries (Cho and Moon, 2013). In fact, the founder of modern economics-Adam Smith - is credited with first describing how division and specialization of labor could increase produced output, which was then also extrapolated from individual businesses to nations by the least-cost producer principle of absolute advantage (A. Smith, 2001/1776). Ricardo (1891/1817) expanded Smith's production and trade theories into the comparative advantage phase by positing that countries should specialize in the production and exchange of the goods in which they are most competitive even if they are the highest absolute cost producers in all goods.

The 20th century brought further progress to these theories. Firstly, the Heckscher-Ohlin model built on the comparative advantage construct by incorporating differentials in factor endowments, whereby countries exported the products using their abundant factors of production and imported products made from the factors that were scarce in their economies (Ohlin, 1957). Around the middle of the century, Harrod (1939) and Domar (1946) independently introduced the so-called Harrod-Domar growth model focused on capital and savings. Then, Solow (1957) contributed to the productivity growth model with attributions beyond capital and labor and to technological change. Subsequently, Mankiw, Romer, and Weil (1992) augmented Solow's theoretical work and tested it with international data, allowing for the recognition of the importance of human capital, and recommended further research of other variables with international dimensions.

Productivity differentials among the world's nations are large. For example, the disparity between the highest-ranked country's productivity and the lowest, among 123 countries tracked by the Conference Board, as measured by the ratio of the former to the latter for year 2014, is about 82, and was substantially lower, at 51, for a group of about 100 countries with available data in 1950 (2015b). Even Solow recently conceded the existence of persistently considerable and unexplained differences in productivity among countries that were not resultant from technological differentials (Baily and Comes, 2014). Hall and Jones (1999) argued that finding an explanation for the sizable disparities in global economic performance is one of economics' most pressing issues. This concern about the unexplained variations in international productivity comparisons was echoed by a number of researchers, who approached this conundrum from different angles as it is summarized below (Acemoglu and Ziliboth, 2001; Del Gatto, Di Liberto, and Petraglia, 2011; Duarte and Restuccia, 2006; Goodridge, Haskel, and Wallis, 2013; Hall and Jones, 1999; Kogel, 2005; Manyika, Woetzel, and Remes, 2014; Sly, 2012).

Hall and Jones (1999) posited that the first step to explaining the differentials in cross-country productivity records may lie in breaking down the aggregate production function, and inquiring into the variation in human and physical capital stock and investment. They claimed that corruption and poor rules of law impede productivity of nations, and that physical capital and education achievement provide only partial clearing up of output per worker differences. Hall and Jones offered social infrastructure, which they defined as "institutions and government policies that determine the economic environment within which individuals accumulate skills, and firms accumulate capital and produce output" (1999, p. 84), as a factor with relatively larger explanatory power for productivity.

Acemoglu and Ziliboth (2001) maintained that technology alone did not account for the vast disparities in national productivity, but that it were the differences in culture, climate, and institutions that contributed to the variations in productivity associated with technologies, such as those between the relatively stronger record observed in the industrialized countries of the North in comparison to the less developed nations of the South. Goodridge, Haskel and Wallis (2013) focused on intangible assets such as software, scientific and non-scientific R\&D, and human and organizational capital as an explanation for productivity growth. Sly (2012) postulated that nations differ in their labor endowments, 
and companies in all countries have to deal with optimally-allocating labor to specific production processes and tasks, matching staff into productive work teams. Researchers at the Bank of International Settlements - a central bank for central banks of the world - recently published a report in which they pointed to extremely low interest rates around most of the world over the last several years as a cause of capital misallocations that put a lid on productivity performance (2015). Kogel (2005) claimed that the youth dependency ratio - the population below working age divided by the population of working age (p. 149) - and overall age composition as an element of cross-country output-per-worker differentials. Clearly, the various explanations from researchers emphasize different factors, but the demographic phenomena appear to be of particular focus of late.

Productivity research continued with scholars seeking further explanations for shortcomings of theories trying to explain the patterns of decelerating productivity growth over time despite various technological advances (Field, 2007; Gordon, 2012, 2015, 2016). At the same time, the role of human capital in productivity has evolved and gained importance in the progressively knowledge-based economy over the last quarter century (Cohen and Soto, 2007; Haines and Sharif, 2006). Hence, it is the linkages to the inherent and attained human factors embodied in happiness and cultural dimensionstogether with the gaps and recommendations of established scholars such as Mankiw, Romer, and Weil (1992), and Holtz-Eakin (1993) for additional research related to human factors in productivity - that provided a basis for exploring the pertinent relationships in this study.

With respect to measuring productivity, a number of scholars suggested that data used for that purpose improved recently, along with increased interest in related research (Dey-Chowdhury, 2008; Feenstra, Inklaar, and Timmer, 2015; Inklaar, Timmer, and van Ark, 2007; J. Smith, 2003; Syverson, 2011; van Ark, 2005; van Ark and McGuckin, 1999). The productivity data have become more detailed, consistent, and more comprehensive in terms of international and temporal coverage, and consequently more comparable (Conference Board, 2015c; Maddison, 2001; Organization for Economic Co-operation and Development, 2016b; J. Smith, 2003; van Ark, 2005). These improvements have allowed for further exploration and analyses of determinants of and relationship behind productivity, and inclusions of larger number of countries and longer time periods.

While the data have been enhanced, there are still some limitations to their use. It ought to be kept in mind that productivity measures are derived as a ratio of aggregate volume of economic output to an input unit. Based on the research by Ross and Murray (2010), real gross domestic product, as opposed to other variables such as gross national income, is the most appropriate measure of output for productivity purposes, and serves as the numerator in the productivity formula. National accounts data, which include GDP, are collected in the United States and many other countries in accordance with the consistent and wide-ranging statistical framework - System of National Accounts (SNA) - developed by the United Nations, together with the World Bank, International Monetary Fund, OECD, and European Commission (United Nations, 2016a). Although some measurement differences in terms of inflation- and foreign exchange-related adjustments, as well as inclusion of certain components and revisions still exist among nations following the SNA conventions, official cross-country GDP data comparability is quite strong (van Ark, 2005).

On the denominator side of the productivity ratio various measures are used, with the most popular being number of persons employed and hours worked. Of these two labor input measures, the employed workers is more accessible, and requires fewer data hurdles to reliably collect across large sets of countries and time (Duarte and Restuccia, 2006; J. Smith, 2003; van Ark and McGuckin, 1999). It needs to also be acknowledged that other cross-national comparability issues such as the second (or third) jobs, as well as informal or underground economies exist with deficient adjustments to the data to account for them (Dey-Chowdhury, 2008; van Ark and McGuckin, 1999). Del Gatto, Di Liberto and Petraglia (2011) proposed that better linkages between macro (national) and micro (firm) analysis levels needed to be established to improve productivity measurement going forward. However, while the data may still be imperfect, in agreement with a number of other productivity researchers, the focus of this study will be on the GDP-per-worker measure as the dependent variable under examination (Conference Board, 2015b; Dey-Chowdhury, 2008; Duarte and Restuccia, 2005; J. Smith, 2003; van Ark and McGuckin, 1999).

The need to focus on analysis and understanding drivers of productivity differentials among countries is believed to be critical for improving economic performance in the years ahead (Manyika, Woetzel, and Remes, 2014). The crucial question related to the factors that cause countries to claim absolute (Smith's) or comparative (Ricardo's) advantage, and what the key endowments of abundance (Heckscher-Ohlin's) 
that lead to outstanding and sustainable productivity outcomes are still remains to be fully understood and answered, and is important to businesses and policy makers seeking an edge in the globalizing economy of today and tomorrow.

\subsection{Culture}

The growing literature on culture presented a picture of a complex construct commonly based on national origin. Such national cultural roots were found to be durable, and brought about culturespecific, or particularism, views of management, as opposed to the universalism, or culture-free, approach. Various researchers established that culture can be impactful on economic and business performance. Guiso, Sapienza, and Zingales recently found evidence that supports culture's influence on societies and helps explain national prosperity (2015). Lenartowicz and Roth (1999) posited that "Understanding the nature and influences of culture is central to international business" (p. 781). In his 1990 seminal article, Michael Porter-Harvard Business School Economics Professor-attributed differences in national cultures or values as key factors in contributing to international competitiveness and performance of nations.

Toward the end of the 20th century, and more recently, research on culture and its dimensions progressed significantly, with Geert Hofstede emerging as the pioneering authority on the subject matter and the international perspective regarding business applications (2001). Overall, Hofstede's culture model has been applied to illuminate various phenomena related to organizations and economies, including growth differentials, identity, and consumer behavior. It is thanks to its relatively straightforward nature and coverage of a large set of nations that the Hofstede seminal framework of national culture has been widely used and cited in numerous academic and business practitioner research efforts (de Mooij and Hofstede, 2010, 2011; Geletkanycz, 1997; Hofstede and Hofstede, n.d.; O'Clock and Devine, 2003; Pressey and Selassie, 2003; Sondergaard, 1994; Triandis, 2004). Generally, understanding of these different cross-cultural dimensions and relationships, explored and explained by Hofstede and other scholars, can enable decision makers at multinationals to further optimize corporate strategies and execution of various business functions to potentially improve productivity and shareholder value creation.

Recently, the list of countries for which the cultural dimensions data are available has been enhanced, facilitating further research use of the related variables and combinations with other constructs (Hofstede and Hofstede, n.d.). Moreover, culture has gained further importance and popularity, and was even selected as the 2014 word of the year (Culture, n.d.).

\subsection{Happiness}

One quest that seems to have characterized the human species since times immemorial is that "virtually everyone wants to be happy" (Frey and Stutzer, 2002, p. 402). According to the subject-related literature, life happiness has fascinated the human race and its scholars since at least ancient times, with Aristotle, Epicurus, Plato, Socrates, Buddha, Confucius, St. Thomas Aquinas, and St. Augustine among the better-known thinkers that have concerned themselves with the goal of happiness and its various aspects (Bok, 2010; Carabelli and Cedrini, 2011; Helliwell, Layard, and Sachs, 2012; Judge and Kammeyer-Mueller, 2011; Kenny and Kenny, 2006; Lyubomirsky and Lepper, 1999; Oishi and Schimmack, 2010; Van Boven and Gilovich, 2003; Veenhoven, 1984). Happiness-related interest was further emphasized in the last few centuries with America's founding fathers incorporating the pursuit of happiness into the American Declaration of Independence of 1776 as an unalienable right (National Archives, n.d.). Nineteenth century utilitarian philosophers, such as Jeremy Bentham and John Stuart Mills, also advocated for happiness for the greatest number of people promoted by actions that maximize net societal benefits (Greenwood, 2002; Karabell, 2014; National Archives, n.d.; Veenhoven, 2010; Velasquez, 2012; Yucel, Elibol, and Dagdelen, 2009).

In his seminal work, Maslow offered a helpful perspective of a hierarchy of needs for understanding the five broad layers of human needs that, in an interconnected fashion, had to be satisfied to result in one's happiness experience (Maslow, 1943). Subsequently, in the last few decades, interest in happiness research has considerably moved forward. Easterlin (1974) is often quoted as the seminal author on the limits of happiness gains based on increases in income or wealth. Concurrently, Katona (1974) studied 
the insights into the consumer behavior as a predictor of larger economic trends, which a number of other researchers advanced further (Bloomberg, 2016; Conference Board, 2016; Gallup, 2016a, 2016b; National Association of Home Builders, 2016; National Federation of Independent Business, 2016; PNC Financial, 2016; University of Michigan, 2016).

Measuring the relationships between happiness and various other socioeconomic variables has continued on to present day, resulting in findings supportive of the following complex factors behind happiness or lack of it: age or lifecycle, gender, (un)employment status, race, family status and time, health, experiential purchases (memorable travel, for instance), business climate, leisure or vacation time, social capital including trust civics and anticorruption, freedom, democracy, work pressures, religion, retirement, physical exercise, and education (Bjornskov, 2003; Bjornskov, Dreher, and Fischer, 2008; Blanchflower and Oswald, 2011; Borooah, 2006; Chuluun and Graham, 2015; Deleire and Kalil, 2010; Di Tella and MacCulloch, 2006; Dunn and Norton, 2013; Easterlin, 2013; Frey and Stutzer, 2000; Helliwell, Layard, and Sachs, 2012; Helliwell and Putnam, 2004; Kahneman and Krueger, 2006; Kahneman, Krueger, Schkade, Schwarz, and Stone, 2004; Karabell, 2014; Oswald, 1997, 2010; Ovaska and Takashima, 2010; Powdthavee, 2010; Van Boven and Gilovich, 2003; Veenhoven, 2010; Wallis, 2005; Weimann, Knabe, and Schob, 2015).

Furthermore, as an example, Porter and his Social Progress Index co-authors recently called for continued studies of the relationship between well-being, or happiness, and other variables such as gross domestic product (GDP) and social progress (Porter, Stern, and Green, 2014). The United Nations recently proclaimed the pursuit of happiness as a fundamental human goal, and in 2012, it also adopted the resolution (number 66/281) declaring March 20th of every year as the International Day of Happiness to be celebrated by all its member nations (United Nations, 2016b). The multidisciplinary field of happiness research has recently enjoyed exponential growth and popularity, including works by well-known scholars, such as the Nobel-Prize winning economists-Stieglitz, Sen, Kahneman, and Deaton (Bjornskov, Dreher, and Fischer, 2008; Blanchflower and Oswald, 2011; Chuluun and Graham, 2015; Clark, Frijters, and Shields, 2008; Deaton, 2010; Deaton and Stone, 2013; Kahneman and Krueger, 2006; MacKerron, 2012; Nobel Prize, 2016; Stiglitz, Sen, and Fitoussi, 2009).

Ultimately, business and economics is largely about people, and additional research on humanizing these pertinent relationships can further add to the body of knowledge about them. Even though research on well-being or happiness has grown rapidly and a large body of literature on productivity has been established, evidence on how the two constructs are related is lacking (Chuluun and Graham, 2015; Oswald, Proto, and Sgroi, 2009). Further research options have been enabled by expanding data sets, such as the recently released cross-cultural database from the sixth wave of the World Value Survey (WVS, n.d.).

\subsection{Other Factors}

This study and its analyses are framed within the context of a globalizing economic reality, where globalization is defined as "the development of an increasingly integrated global economy marked especially by free trade, free flow of capital, and the tapping of cheaper foreign labor markets" (Merriam-Webster, 2012a, p. 532). Moreover, major demographic changes, as well as widespread technological advances, such as the proliferation of the Internet, mobile telephony, and robotics, have put additional pressure on productivity growth outcomes (Baily and Comes, 2014; Bureau of Labor Statistics, 2012b, 2013; Dent, 2014; Eichengreen, 2015; Fry, 2015; Goodhart and Erfurth, 2014; Graetz and Michaels, 2015; Maddison, 2001; Manyika, Woetzel, and Remes, 2014; Nyce, 2007; the Economist Intelligence Unit, 2015; United Nations, 2016c; World Trade Organization, 2015).

For instance, as populations and workforces age and decelerate in growth throughout large swaths of the world, reliance on productivity will increase substantially if economic growth and standards of living are to be maintained or improved. This unease about the impact of unfavorable demographics on productivity and overall economic growth was increasingly brought up in the literature, including the seminal authors such as Solow (Baily and Comes, 2014) and Hansen (1939), as well as others (Clements, Dybczak, Gaspar, Gupta, and Soto, 2015; Dent, 2014; Dobbs, Manyika, and Woetzel, 2015; Economist Intelligence Unit, 2015; Eichengreen, 2015; Goodhart and Erfurth, 2014; Manyika, Woetzel, and Remes, 2014; Nyce, 2007). This fact is justifiably important, as productivity is dependent on the availability of workers and their efficiency (Nyce, 2007). These phenomena further justify the need to enhance the 
understanding of the complex relationships between productivity and other constructs, such as happiness and culture.

\section{Methodology}

This section of the article describes the methodology employed, including the pertinent research questions, hypotheses tested, variables used, and the data collection and analysis including the estimation method.

\subsection{Research Questions}

The study revolved around one umbrella research question and two sub-questions, formulated as the following:

- RQ: How is national productivity related to national life happiness and Hofstede's five cultural dimensions in a cross-national context?

o RQ 1: How is national productivity related to national life happiness in a cross-national context?

o RQ 2: How is national productivity related to Hofstede's five cultural dimensions in a cross-national context?

\subsection{Variables}

The study examined the relationships between one dependent and several independent variables, as defined in the sub-sections below.

\subsubsection{Dependent Variable.}

The construct of productivity is defined as a ratio of a volume measure of economic output to a volume measure of input used in a production of a good or service, as per the Organization for Economic Co-operation and Development-OECD (2013). The productivity construct is used to measure how efficiently production inputs such as labor are converted into a given level of economic output within a unit of time (Organization for Economic Co-operation and Development, 2013, 2015; van Ark, 2005). The dependent variable - productivity - was defined as real (inflation adjusted) gross domestic product per person (worker) employed per year (Conference Board, 2015b). The constituent variable-GDPwas defined, in accordance with the international guidelines provided by the United Nations System of National Accounts 2008, as an aggregate measure of production, equal to the sum of the gross values added of all resident institutional units engaged in production (plus any taxes and minus any subsidies on products not included in the value of their outputs) in an economy during a given time period (Organization for Economic Co-operation and Development, 2016c; United Nations, 2016a). The mean national values of GDP per person employed, expressed per year in 2014 constant U.S. dollars in purchasing power parity terms, were used for operationalizing the productivity variable.

\subsubsection{Independent Variables.}

Six independent, or explanatory, variables are included in the study. The first explanatory variablehappiness - was defined as one's overall satisfaction with one's life (Graham, 2005; Veenhoven, 2010; World Values Survey, n.d.a). This is an evaluative meaning of happiness encapsulating persons' broad or global assessment of life overall, synonymous with life satisfaction or societal well-being (Veenhoven, $2005,2010)$, and in contrast to the affective type that refers simply to a momentary emotional feeling of happiness. The values of this variable ranged between 1 and 10. The mean values for all the participants in the surveys for each country by World Values Survey (n.d.a) served for operationalizing the happiness variable.

The other five independent variables all pertained to Hofstede's cultural dimensions, and were defined as the following: a) individualism-collectivism - the extent to which society members identify themselves as individuals versus group members; (b) power distance-the degree to which society members anticipate and accept the distribution of power; (c) masculinity-femininity differences in attitudes toward societal roles between the two sexes; (d) uncertainty avoidance - the self-programming of societies towards dealing with ambiguity and uncertainty; and, (e) long-short orientation-relative 
differences in significance of perseverance, thrift, and respect for tradition, which was also otherwise referred to as Confucian dynamism (de Mooij and Hofstede, 2010, 2011; Hofstede, 1981, 1984, 1994, 1998a, 1998b, 2001, 2009; Hofstede and Bond, 1988; Hofstede and Hofstede, n.d.; Hofstede and Minkov, 2010). The underlying construct of culture can be defined as "the collective programming of the human mind that distinguishes the members of one human group from those of another. Culture, in this sense, includes values" (Hofstede, 2001, p. 9). Operationally, the values of Hofstede's cultural dimensions were compiled on a scale from 0 to 100 .

The research questions about the relationships among the above-listed variables were addressed by testing the following one omnibus hypothesis, four main hypotheses, and five sub-hypotheses, shown below as null and alternative (sub)hypotheses:

$\mathbf{H}_{0}$ : There will be no statistically significant relationship between national productivity and life happiness and Hofstede's five cross-cultural dimensions.

$\mathbf{H}_{\mathrm{A}}$ : There will be a statistically significant relationship between national productivity and life happiness and Hofstede's five cross-cultural dimensions.

$\mathbf{H}_{01}$ : There will be no statistically significant relationship between national productivity and life happiness.

$\mathbf{H}_{\mathbf{A} 1}$ : There will be a statistically significant relationship between national productivity and life happiness.

$\mathbf{H}_{02}$ : There will be no statistically significant relationship between national productivity and Hofstede's five cross-cultural dimensions.

$\mathbf{H}_{\mathrm{A} 2}$ : There will be a statistically significant relationship between national productivity and Hofstede's five cross-cultural dimensions.

$\mathbf{H}_{02 \mathbf{a}}$ : There will be no statistically significant relationship between national productivity and power distance.

$\mathbf{H}_{\mathrm{A} 2 \mathrm{a}}$ : There will be a statistically significant relationship between national productivity and power distance.

$\mathbf{H}_{02 \mathrm{~b}}$ : There will be no statistically significant relationship between national productivity and uncertainty avoidance.

$\mathbf{H}_{\mathrm{A} 2 \mathrm{~b}}$ : There will be a statistically significant relationship between national productivity and uncertainty avoidance.

$\mathbf{H}_{\mathbf{0 2}}$ : There will be no statistically significant relationship between national productivity and individualism-collectivism.

$\mathbf{H}_{\mathrm{A} 2 \mathrm{c}}$ : There will be a statistically significant relationship between national productivity and individualism-collectivism.

$\mathbf{H}_{02 \mathrm{~d}}$ : There will be no statistically significant relationship between national productivity and masculinity-femininity.

$\mathbf{H}_{\mathrm{A} 2 \mathrm{~d}}$ : There will be a statistically significant relationship between national productivity and masculinity-femininity.

$\mathbf{H}_{02 \mathrm{e}}$ : There will be no statistically significant relationship between national productivity and longshort orientation.

$\mathbf{H}_{\mathrm{A} 2 \mathrm{e}}$ : There will be a statistically significant relationship between national productivity and longshort orientation.

$\mathbf{H}_{03}$ : There will be no statistically significant relationship between national productivity and life happiness and some combination of Hofstede's five cross-cultural dimensions.

$\mathbf{H}_{\mathrm{A} 3}$ : There will be a statistically significant relationship between national productivity and life happiness and some combination of Hofstede's five cross-cultural dimensions.

$\mathbf{H}_{04}$ : There will be no statistically significant relationship between national productivity and some combination of Hofstede's five cross-cultural dimensions.

$\mathbf{H}_{\mathrm{A} 4}$ : There will be a statistically significant relationship between national productivity and some combination of Hofstede's five cross-cultural dimensions.

\subsection{Research Design}

The proposed topic was examined through the (post)positivist prism. In accordance with the positivist philosophical tradition, ontologically, this subject matter was observable and measurable, and 
epistemologically and axiologically, in an objective fashion using quantitative methods to understand the evaluated phenomena (Creswell, 2009; Crotty, 2009; Swanson and Holton, 2005). Correspondingly, the research design selected for the study was quantitative non-experimental. Specifically, it was explanatory statistical, which facilitated using statistical models for exploring the hypothesized relationships between the dependent and independent variables in question. This approach allowed for quantitatively testing and answering the hypotheses and research questions raised in this study, which led to conclusions and recommendations for business and policy decision making. This design was also well-aligned with research approaches commonly applied in the relevant works found in the scholarly literature.

\subsection{Sample}

National markets served as the target population of interest in this study. A national market refers to a marketplace within an economy of a nation (for example, the American or German economy), with all its forces of demand and supply in which economic agents transact. It is a place where businesses operate for various purposes related to production or sales, etc. of goods and services, and find opportunities to maximize their productivity, and, ultimately profits or shareholder value. The related term of an economy can be defined as an economic system or structure of economic life in a country (Merriam-Webster, 2012b, p. 394). In a globalizing economy, productivity outcomes are of high importance to businesses operating in varying national markets around the world, which made national markets the target population of this study. In this article, national markets are used interchangeably with national economies, and countries.

National markets served as the primary unit of analysis. These national markets are business units of interest to business organizations either already operating abroad or planning to expand beyond their existing markets, as well as to economic policy makers. Analysis of such units with respect to happiness and cultural dimensions was envisioned to be helpful to businesses interested in improving their productivity and, consequently, overall performance when operating in cross-national settings.

Three databases constituted the sampling frame for the study: (a) Conference Board's Total Economy Database (2015b) for productivity; (b) World Values Survey database (n.d.a) for life happiness; and, (c) Hofstede's database (n.d.) for cultural dimensions. These three databases provided the sample data. The productivity database included 123 countries, with data in terms of GDP per person employed provided for all 123 countries, while the data measured in GDP-per-hour was available for 66 countries (Conference Board, 2015b). The Conference Board's database provided productivity data through the latest historical year 2014 (selected for the analysis), with a number of countries traced back to year 1950. The data from this source were made readily available to the public for research purposes without permission.

The life happiness database, in particular its latest Wave 6 completed in 2014, covered 59 countries based on responses from approximately 85,000 survey respondents averaging more than 1,440 per country in the World Values Survey database (n.d.a). The data from this source were made freely available to the public for research purposes without additional permissions.

The latest version of Hofstede's cultural dimensions database included 108 countries, 63 of which contained values for all five dimensions under analysis in this study. The original database was based on responses from more than 116,000 participants (Hofstede, 2001; Hofstede and Hofstede, n.d.). These data were available for personal, non-commercial analysis purposes such as scholarly research without permission.

\subsection{Sample Size}

The largest number of countries, or national markets, for which the available data in the three databases could be matched (akin to the greatest common denominator) among the study's variables served as the sample size used in the study. This sample size was 33 national markets with data for all the dependent and independent variables under consideration to address the study's umbrella research question. The sample size considering the dependent productivity variable and the happiness independent variable (RQ 1) was 54 national markets, while the sample size for the dependent productivity variable and the cultural dimensions independent variables (RQ 2) was 62 national markets. 
Overall, the databases in the sample covered diverse groups of less-developed and advanced, small, medium, and large economies across all the continents (barring the practically unpopulated Antarctica). The sample of the 33 national markets was sizable from a global standpoint, as it captured close to two thirds of the world's total population and trade, as measured by merchandise exports, and nearly three quarters of the global economic activity, as approximated by gross domestic product (International Monetary Fund, 2015; United Nations, 2015; World Trade Organization, 2015). The sample of national markets was also aligned with the unit of the analysis as stated in the previous section.

\subsection{Data Collection}

The pertinent data were collected from the above-listed databases. These publicly-available secondary data were found accessible from the respective sources without additional permissions, and were electronically-downloaded in either Microsoft (MS) Excel or SPSS (Statistical Package for Social Sciences) formats. Upon collection, the data were further formatted, as well as cleaned and processed to make them usable as input into the quantitative analysis in this study. The countries among the variables for which the data were available in these three databases were matched for the purposes of conducting the quantitative analysis. Because previously-collected survey data pertinent to the variables under examination were utilized in the study, no recruitment, selection, or assignment of survey participants were required. These data were subjected to a quantitative analysis as described below.

\subsection{Data Analysis}

Following the scale data collection for all the variables of interest, data cleaning and processing occurred. The pertinent variables data were at the interval scale level. Using statistical applications, such as SPSS, and MS Excel (combined with Palisade StatTools), as appropriate, the data were used to develop various tables and charts. Subsequently, the data and the associated graphics were diagnosed and analyzed by looking for themes, relationships, patterns, outliers, and initial assessment ideas. Descriptive statistics such as mean, median, standard deviation, range, outliers, skewness, and kurtosis were derived. Pearson product-moment correlation coefficient $(r)$ was used as a measure of bivariate linear relationships between the variables. A summary of the descriptive statistics pertaining to the sample is presented in Table 1.

Table1. Sample descriptive statistics

\begin{tabular}{lrrrrrrrr}
\hline Variable & $N$ & \multicolumn{1}{c}{ Mean } & Minimum Maximum & Range & SD & Skewness & Kurtosis \\
\hline Productivity & 33 & 59,378 & 13,091 & 131,595 & 118,504 & 31,276 & 0.41 & -0.57 \\
Happiness & 33 & 7.1 & 5.1 & 8.5 & 3.4 & 0.7 & -0.80 & 2.30 \\
IDV & 33 & 40 & 13 & 91 & 78 & 23 & 0.83 & -0.33 \\
PDI & 33 & 62 & 22 & 100 & 78 & 19 & -0.04 & -0.36 \\
MAS & 33 & 49 & 5 & 95 & 90 & 18 & -0.22 & 1.05 \\
UAI & 33 & 66 & 8 & 98 & 90 & 24 & -0.60 & -0.57 \\
LTO & 33 & 48 & 13 & 100 & 87 & 26 & 0.50 & -0.89 \\
\hline
\end{tabular}

Where PDI denotes power distance, IDV denotes individualism, MAS denotes masculinity,

UAI denotes uncertainity avoidance, and LTO denotes long-term orientation.

\subsubsection{Estimation Method}

In order to explore the relationships among the above-listed variables, as per the hypotheses of interest listed earlier in this article, a multiple regression analysis technique was chosen. Based on the literature review, the regression method was also found to be used by various other researchers examining the relationships pertinent to productivity. An econometric technique known as ordinary least squares (OLS) regression model was employed to serve as the primary quantitative estimation 
method or model in the study. A multivariate regression analysis determines the mathematically correlative relationships between identified two or more independent, or predictor, variables and the dependent or outcome variable while aiming to minimize the sum of squares of the differences between the observed responses in the data and those predicted by a function of independent variables (Copper and Schindler, 2011; Field, 2009; Griffiths, Hill, and Judge, 1993; Swanson and Holton, 2005; Vogt, 2007). When using regression techniques, one needs to ensure that the regression model and its inputs and outputs make intuitive sense. The multivariate regression technique aligned well with the research question that pertained to measuring the relationships between the dependent and independent variables, and the literature review findings.

As part of the regression diagnostics fundamental assumptions were also checked. These regression model assumptions included: (a) non-zero variance of predictors using standard deviation and range statistics; (b) independence of errors using the Durbin-Watson test; (c) linearity of the relationships between the outcome and the regressor variables using scatter plots; (d) homoscedasticity using residual plots; and, (e) distribution normality using histograms, P-P (probability-probability) plots, as well as the Kolmogorov-Smirnov test (Field, 2009; Swanson and Holton, 2005; Vogt, 2007).

$F$ tests for regression model overall fit with all the multivariate coefficients were derived for the relationships testing. Multiple model runs were conducted for the different combinations of the variables of interest. $F$ test statistics in ANOVA tables are ratios that capture the proportion of the explained variation in the dependent variable relative to the unexplained variation in the model (Copper and Schindler, 2011; Field, 2009; Griffiths, Hill, and Judge, 1993; Vogt, 2007). Probability values ( $P$ values $)$ were also examined for testing significance. The level of significance $(\alpha)$, or probability of Type I errorrejection of the null hypothesis when it is true - was set at 0.05. Adjusted, for non-spurious explanatory additions to the model, $R^{2}$ - the coefficient of determination-along with other diagnostic measures, such as, $t$ statistics for individual predictor slope coefficients, were also used to assess the model results. Other checks in the analysis also included logical coefficient signs, with intuitive understanding of any ensuing correlations, as well as multicollinearity testing with measures such as variance inflation factor (VIF), and the related tolerance statistics (Cooper and Schindler, 2011; Field, 2009; Vogt, 2007). Additionally, transformations, such as log, square, square root, and reciprocal, of the data were performed to check if the normality assumptions and fits were improved with multivariate regressions on such transformed data (Field, 2009).

Productivity was hypothesized to be a function of the values of life happiness and the cultural dimensions as presented in Equation 1:

$$
p \approx f\left(L H, \mathrm{C}_{i}, \beta_{i}\right)
$$

where $\mathrm{P}$ denotes productivity, LH denotes life happiness, $\mathrm{C}_{i}$ denotes cultural dimensions, and $\beta_{i}$ denotes parameters.

This function can also be depicted in the following linear regression form-Equation 2 :

$$
p=\beta_{0}+\beta_{1} l h_{i}+\beta_{2} p d i_{i}+\beta_{3} u a i_{i}+\beta_{4} i d_{i}+\beta_{5} \text { mas }_{i}+\beta_{6} \text { lto }_{i}+\varepsilon
$$

where $\mathrm{p}$ denotes productivity, lh denotes life happiness, pdi denotes power distance, uai denotes uncertainty avoidance, idv denotes individualism, mas denotes masculinity, lto denotes long-term orientation, $\beta_{i}$ denotes regression coefficients, $\varepsilon$ denotes an error term, and subscript $i$ denotes a particular observation.

The values of the constant and slope coefficients for each of the independent variables in this multivariate regression equation were also derived to establish the relationship among these variables. The signs and strength of the correlation coefficients between productivity and life happiness, as well as each of the five cultural dimensions individually, were determined as well.

\section{$4 \quad$ Results Summary}

Based on the results of the hypotheses and sub-hypotheses testing, the study's omnibus null hypothesis, all four main null hypotheses, and two of the five null sub-hypotheses were rejected in favor of their alternative versions. Table 2 summarizes the support or lack thereof for each of the 10 alternative hypotheses and sub-hypotheses tested in the study. The results revealed the answer to the study's umbrella research question with respect to the nature of the relationship between national productivity, 
life happiness and cultural dimensions being moderately strong, which is similar to the nature of the linear relationship between national productivity and life happiness at the core of the research subquestion RQ 1. The relationship between national productivity, and Hofstede's cultural dimensions sought in sub-question RQ 2 was found to be of mixed nature depending on the cultural variables under examination.

Table 2. Summary results of study hypotheses testing

\begin{tabular}{|c|c|c|}
\hline $\begin{array}{l}\text { Alternative Hypothesis } \\
\text { Designation }\end{array}$ & Hypothesis Statement & Result \\
\hline $\mathrm{H}_{\mathrm{A}}$ & $\begin{array}{l}\text { There will be a statistically significant relationship between national productivity and } \\
\text { life happiness and Hofstede's five cross-cultural dimensions. }\end{array}$ & Supported \\
\hline $\mathrm{H}_{\mathrm{A} 1}$ & $\begin{array}{l}\text { There will be a statistically significant relationship between national productivity and } \\
\text { life happiness. }\end{array}$ & Supported \\
\hline $\mathrm{H}_{\mathrm{A} 2}$ & $\begin{array}{l}\text { There will be a statistically significant relationship between national productivity and } \\
\text { Hofstede's five cross-cultural dimensions. }\end{array}$ & Supported \\
\hline $\mathrm{H}_{\mathrm{A} 2 \mathrm{a}}$ & $\begin{array}{l}\text { There will be a statistically significant relationship between national productivity and } \\
\text { power distance. }\end{array}$ & Supported \\
\hline $\mathrm{H}_{\mathrm{A} 2 \mathrm{~b}}$ & $\begin{array}{l}\text { There will be a statistically significant relationship between national productivity and } \\
\text { uncertainty avoidance. }\end{array}$ & Unsupported \\
\hline $\mathrm{H}_{\mathrm{A} 2 \mathrm{c}}$ & $\begin{array}{l}\text { There will be a statistically significant relationship between national productivity and } \\
\text { individualism-collectivism. }\end{array}$ & Supported \\
\hline $\mathrm{H}_{\mathrm{A} 2 \mathrm{~d}}$ & $\begin{array}{l}\text { There will be a statistically significant relationship between national productivity and } \\
\text { masculinity-femininity. }\end{array}$ & Unsupported \\
\hline $\mathrm{H}_{\mathrm{A} 2 \mathrm{e}}$ & $\begin{array}{l}\text { There will be a statistically significant relationship between national productivity and } \\
\text { long-short orientation. }\end{array}$ & Unsupported \\
\hline $\mathrm{H}_{\mathrm{A} 3}$ & $\begin{array}{l}\text { There will be a statistically significant relationship between national productivity and } \\
\text { life happiness and some combination of Hofstede's five cross-cultural dimensions. }\end{array}$ & Supported \\
\hline $\mathrm{H}_{\mathrm{A} 4}$ & $\begin{array}{l}\text { There will be a statistically significant relationship between national productivity and } \\
\text { some combination of Hofstede's five cross-cultural dimensions. }\end{array}$ & Supported \\
\hline
\end{tabular}

Given the study results, the variables evidenced to show considerable promise, either singularly or in combination, for productivity-enhancing outcomes are individualism, power distance, and life happiness. Additional results detail is provided in Table A1 in the Appendix.

\section{Discussion and Implications of the Study Results}

The findings discussed above have various theoretical and practical implications, and are the focus of this section. Drawing on the literature concerning national productivity, this study endeavored to contribute to the body of knowledge related to national productivity drivers. As the literature review established, a lot has been learned about the factors influencing productivity through modern times; however, full understanding and the answers behind national productivity outcomes were still left indeterminate. This study attempted to search for further comprehension of the forces behind productivity extending beyond the key related theories such as those captured in Solow's growth model (1956, 1957) and its augmented version with human capital (Mankiw, Romer, and Weil, 1992), the specialization of labor and absolute advantage (A. Smith, 2001/1776), comparative advantage (Ricardo, 1891/1817), and the factor endowments (Ohlin, 1957), in an international context.

This task was undertaken by humanizing the potential explanations behind national productivity performance with constructs of happiness and culture. While some nations develop advantages or use factor endowments that they have plenty of, they (and concerned businesses) may also be able to tap into their underutilized resources of happiness or certain cultural traits to further understand and improve their productivity performance. Solow $(1956,1957)$ offered great insight into productivity 
research by incorporating technological progress in addition to capital and labor factors; however, along with other scholars, he self-admittedly acknowledged imperfections in his theory's ability to fully explain productivity despite realized technological advancements. In subsequently related efforts, Mankiw, Romer, and Weil (1992) augmented Solow's work, recognizing the significance of human capital and international perspectives. This study strove to build on these recommendations by exploring current relationships that delve into the human factor, with the happiness and cultural dimensions in a crossnational context. This effort yielded some statistically significant relationships that may add to the understanding of what drives national productivity, and how businesses can boost it to their advantage.

The study findings, with evidence supporting the existence of relationships between national productivity and cultural dimensions, also broached an evaluation of some of the culture-related themes in business literature. Through the results that are supportive of the linkages between national productivity and culture, the study provided some confirmation for the cultural particularism view, which underscored features that are culturally-specific behind patterns of cultural differences in business performance. In congruence with this cultural perspective, the study results call for customization of business strategies and their execution to cultural conditions in order to more effectively, relative to culture-free approaches, push performance forward.

However, the study findings with respect to the long-term orientation cultural dimension were mixed. Specifically, this independent variable was found to not have a particularly strong correlation with national productivity, and the regression of it singularly rendered it insignificant as a predictor of national productivity. This result was in contrast to Hofstede and Bond's (1988) seminal findings, attributing this dimension to the extraordinarily strong economic growth of the long-term orientation high-scoring five Asian Dragons. It should be noted, however, that while those findings were convincing around their publication time when the Asian Dragons had grown very robustly from the 1960s through the 1980s, their overall economic growth rates (as measured in real GDP-per-capita terms) decelerated dramatically since the 1990s, of which the Japanese anemic economic performance is a prime example (Conference Board, 2015b). Moreover, the Asian Dragons experienced further western business influences, spread via globalization over the last few decades, and at the same time, the relative convergence of productivity performance from the low long-term orientation ranked economies, such as the United States of America, Australia, and Ireland has occurred. Therefore, it is perhaps not surprising that given the more recent productivity-specific experience of the Asian Dragons, the previously derived link between long-term orientation and economic growth currently appears more tenuous and is subject to revisitation.

Nevertheless, the long-term orientation index still served as a statistically significant regressor of national productivity when combined with other explanatory variables, particularly as a pair with the power distance cultural dimension. This mixed finding with respect to long-term orientation, as well as the less influential masculinity and uncertainty avoidance, may be a testament to Hofstede's continued statement that culture may be a necessary but not sufficient force for understanding and explaining economic growth.

The emerging, but limited, research findings pertaining to the relationship between national productivity and happiness found in the literature were also confirmed in this study. Based on the results of the regression modeling, the statistical evidence showed that a statistically significant relationship between happiness and national productivity exists. However, the explanatory power of happiness for national productivity predicting purposes was not found to be very strong.

Beyond these more theoretical confirmations and expansions of some of the results previously reported in the related literature, the study offers some practical implications for businesses interested in pushing their productivity performance forward. The study results provided evidence of specific relationships between national productivity and life happiness, as well as the different cultural dimensions, either separately or in combinations. While the human factors of life happiness and cultural dimensions on which this study focused do not provide full answers to the relationships pertaining to productivity, they may be used to supplement the other ones previously identified in the literature such as the augmented Solow model. The evaluated in the study relationships can serve as selection guidelines for businesses to gain a competitive edge in otherwise competitive environments where overall productivity performance at the national level has recently been challenging in many economies.

In particular, the study findings suggest that happier nations, ceteris paribus, have a potential to yield stronger productivity performance. Hence, establishing or continuing production in happiness- 
strong markets in North American nations such as the United States or Mexico, Latin American nations such as Columbia or Brazil, and in Northern European economies such as Sweden and the Netherlands, may be beneficial for productivity results. In contrast, doing business in countries with low scores on happiness such as the African nations of Egypt, Tunisia, or the Middle Eastern nation of Yemen may not be as rewarding from a productivity standpoint.

From a culture-related standpoint, individualistic countries such as the United States, Australia, Great Britain, and Canada show high promise for productivity-oriented business mindsets, while the collectivist nations of Venezuela, Pakistan, and Indonesia are not as attractive. Power distance is evidenced to be another cultural dimension, by itself or in combination with individualism, that can be helpful in choosing productivity-supportive outcomes. In this regard, markets scoring low (because of the negative slope in the relevant equations) would provide preferred locations. These include the economies of Austria as well as Scandinavia. On the opposite end of the spectrum, the Southeast Asian markets of Malaysia and the Philippines, as well as Russia and Romania may be poor choices.

Overall, the general theme of the national markets that are likely to be supportive of strong productivity outcomes favors the democratic, free-market, largely individualistic, and at the same time relatively happiness-rich, economies of North America, and Northern Europe, while those in much of Africa, some in South and Southeast Asia, and some in South America look less favorable. While these characteristics may be helpful for businesses in guiding their market selections, they may also be worth a consideration for government policy makers focusing on improvements to their nations' rankings in terms of productivity enhancing factors such as life happiness, and individualism.

\section{$6 \quad$ Limitations}

The study included a number of limitations pertaining to the sample and methodology used, which in turn, impacted its findings. The study focused on a snapshot of relationships in time, but productivity can change over time, and progressing globalization may contribute to blending of cultures and happiness levels. Consequently, recommendations for further related research were made to improve on the current study results. These encompassed using a larger sample, disaggregating the national-level relationships into industry and regional levels, as well as an addition of a temporal element, and an incorporation of the recent sixth cultural dimension of indulgence versus restraint.

\section{$7 \quad$ Recommendations for Further Research}

The purpose of this section is to provide recommendations for further research related to this topic, given the limitations and delimitations of the current study. One of the recommendations is that future attempts to study the relationships between productivity, life happiness, and cultural dimensions draw on larger samples. This could be achieved by employing other relevant databases, particularly for the happiness-related variable, which in this study was approximated by the smallest number (of the three databases) of available national estimates. For instance, private sources such as Gallup-Healthways conduct surveys of happiness or well-being in a larger number of countries (2015). Researchers may also be advised to utilize future waves of the World Value Survey, which could provide pertinent data for a greater number of national markets.

It is also recommended that, to the extent that the future data allow, similar explanatory analysis be conducted with disaggregate data. For instance, examining the relationships for productivity of specific sectors or industries, as opposed to the national aggregates as in the current study, may provide additional or more pertinent lessons for businesses operating in particular industries across multiple national markets. A temporal analysis, looking at changes in the relationships over time, may also be helpful in understanding potential dynamic effects of the linkages with productivity that can then yield improved outcomes for years to come. Subnational analyses are also suggested as potentially worthwhile, as regional markets may in some cases significantly deviate from the national averages with respect to their productivity, happiness, and cultural characteristics. While these disaggregated analyses may currently be restricted by data unavailability, as the required data accessibility improves with technological progress going forward, such evaluations may be quite valuable. 
Future related research efforts should also include Hofstede's latest cultural dimension of indulgence versus restraint. An inclusion of this culture-related variable may change the outcomes of the relationships established based on the first five dimensions, and potentially provide further depth of understanding of the cultural forces behind international productivity differentials. Moreover, it is suggested here that exploring the non-linear nature of the relationships between national productivity and happiness, and cultural dimension may also lead to new and potentially improved insights to be gained.

Lastly, as the established relationships between the variables of interest could change over time, they may warrant monitoring, and strategic and tactical adjustments going forward.

\section{Conclusion}

Recent productivity trends in much of the world economy show worrisome signs, and international productivity differentials remain less than fully explained, calling for less orthodox approaches to understanding productivity including analyses of human factors. Overall, no holy grail of the multifaceted productivity subject matter was discovered in this study. However, based on the findings applying the country rankings in the databases used in the study, ceteris paribus, businesses concerned about favorable productivity outcomes are likely to reap or maintain a competitive advantage by operating in economies characterized by sound democracy, free-markets, rule of law, happiness, and individualism, such as those found in North America and Northern Europe.

\section{References}

1. Acemoglu, D., and F. Zilibotti, "Productivity differences," Quarterly Journal of Economics, vol. 116, no. 2, pp. 563-606. 2001.

2. Baily, M., and F. Comes, "Prospects for growth: An interview with Robert Solow. McKinsey Quarterly, vol. 3, pp. 151-157, 2014. Available: http://www.mckinsey.com/insights/mckinsey_quarterly.

3. Bank of International Settlements. 85th annual report. 2015

Available: http://www.bis.org/publ/arpdf/ ar2015e.pdf.

4. Bergeaud, A., G. Cette, and R. Lecat, "Productivity trends from 1890 to 2012 in advanced countries," Banque de France Working Papers, vol. 475, pp. 1-48, 2014.

Available: http://papers.ssrn.com/sol3/papers.cfm? abstract_id=2414367.

5. Bjornskov, C. "The happy few: Cross-country evidence on social capital and life satisfaction," Kyklos, vol. 56, no.1, pp. 3-16, 2003.

6. Bjornskov, C., A. Dreher, and J. Fischer, "Cross-country determinants of life satisfaction: Exploring different determinants across groups in society," Social Choice and Welfare, vol. 30, no. 1, pp. 119-173, 2008.

7. Blanchflower, D., and A. Oswald, "International happiness: A new view on the measure of performance," Academy of Management Perspectives, vol. 25, no. 1, pp. 6-22, 2001.

8. Bloomberg. Consumer comfort index. 2016.

Available: http://topics.bloomberg.com/bloomberg-consumer-comfort-index/

9. Bok, S. Exploring happiness from Aristotle to brain science. Yale University Press, 2010.

10.Borooah, V. "How much happiness is there in the world? A cross-country study," Applied Economics Letters, vol. 13, no. 8, pp. 483-488, 2006.

11.Brynjolfsson, E. "The productivity paradox of information technology," Communications of the ACM, vol. 36, no. 12, pp. 67-77, 1993.

12.Bureau of Labor Statistics. International comparisons of manufacturing productivity and unit labor cost trends, 2011, 2012a. Available: http://www.bls.gov/news.release/pdf/prod4.pdf

13.Bureau of Labor Statistics. Labor force projections to 2020: A more slowly growing workforce. 2012b. Available: http://www.bls.gov/opub/mlr/2012/01/art3full.pdf

14.Bureau of Labor Statistics. Labor force projections to 2022: The labor force participation rate continues to fall. 2013. Available: http://www.bls.gov/opub/mlr/2013/article/pdf/labor-force-projections-to-2022-the-labor-forceparticipation-rate-continues-to-fall.pdf 
15.Bureau of Labor Statistics. Productivity and costs, first quarter 2015. 2016a.

Available: http://www.bls.gov/ news.release/prod2.nr0.htm.

16.Bureau of Labor Statistics. Preliminary multifactor productivity trends, 2014. 2016b.

Available: http://www.bls.gov/news.release/prod3.nr0.htm

17.Carabelli, A., and M. Cedrini, "The economic problem of happiness: Keynes on happiness and economics," Forum for Social Economics, vol. 40, no. 3, pp. 335-359, 2011.

18.Cho, D., and H. Moon, From Adam Smith to Michael Porter: Evolution of competitiveness theory. World Scientific \& Imperial College Press, 2013.

19. Chuluun, T., and C. Graham, "Local culture and firm behavior: Do firms in happy places invest more," Social Sciences Research Network, pp. 1-30, 2015.

20.Clark, A., P. Frijters, and M. Shields, "Relative income, happiness, and utility: An explanation for the Easterlin paradox and other puzzles," Journal of Economic Literature, vol. 46, no. 1, pp. 95-144, 2008.

21.Clark, G. "Winter Is Coming: Robert Gordon and the Future of Economic Growth," American Economic Review, vol. 106, no. 5, pp. 68-71, 2016.

22.Clements, B., K. Dybczak, V. Gaspar, S. Gupta, and M. Soto, "The fiscal consequences of shrinking populations," International Monetary Fund Staff Discussion Note, vol. 21, pp. 1-34, 2015.

23.Cohen, D., and M. Soto, "Growth and human capital: good data, good results," Journal of Economic Growth, vol. 12, no. 1, pp. 51-76, 2007.

24. Conference Board. Productivity brief 2015: Global productivity growth stuck in the slow lane with no signs of recovery in sight. 2015a. Available: http://www.conference-board.org/retrievefile.cfm?filename=The-ConferenceBoard-2015-Productivity-Brief.pdf\&type=subsite

25. Conference Board. Total Economy Database. 2015b.

Available: http://www.conference-board.org/data/economydatabase/

26. Conference Board. Consumer confidence index. 2016

Available: http://www.conference-board.org/data/consumerconfidence.cfm

27.Cooper, C., and P. Schindler, Business research methods (11th ed.). McGraw-Hill, 2011.

28.Creswell, J. Research design: Qualitative, quantitative, and mixed methods approaches (3rd ed.). Sage Publications, Inc., 2009.

29. Crotty, M. The foundations of social research: Meaning and perspective in the research process. Sage Publications, 2009.

30.Culture. [2014 word of the year] In Merriam-Webster's collegiate dictionary. n.d. Available: http://www.merriam-webster.com/top-ten-lists/2014-word-of-the-year/culture.html

31.de Mooij, M., and G. Hofstede, "The Hofstede model," International Journal of Advertising, vol. 29, no. 1, pp. $85-110,2010$.

32.de Mooij, M., and G. Hofstede, Cross-cultural consumer behavior: A review of research findings. Journal of International Consumer Marketing, vol. 23, no. 3/4, pp. 181-192, 2011.

33.Deaton, A. "In pursuit of happiness," The Lancet, vol. 376, no. 9754, p. 1729, 2010.

34.Deaton, A., and A. Stone, "Two happiness puzzles," The American Economic Review, vol. 103, no. 3, pp. 591$597,2013$.

35.Deleire, T., and A. Kalil, "Does consumption buy happiness? Evidence from the United States," International Review of Economics, vol. 57, no. 2, pp. 163-176, 2010.

36.Del Gatto, M., A. Di Liberto, and C. Petraglia, "Measuring productivity," Journal of Economic Surveys, vol. 25, no. 5, pp. 952-1008, 2011.

37.Dent, H. The demographic cliff: How to survive and prosper during the great deflation of 2014-2019. Penguin Random House Company, 2014.

38.Dey-Chowdhury, S. "International comparisons of productivity: An update to understanding revisions," Economic and Labour Market Review, vol. 2, no. 3, pp. 34-42, 2008.

39.Di Tella, R., and R. MacCulloch, "Some uses of happiness data in economics," The Journal of Economic Perspectives, vol. 20, no. 1, pp. 25-46, 2006.

40.Domar, E. "Expansion, rate of growth, and employment," Econometrica, vol. 14, no. 2, pp. 137-147, 1946.

41.Duarte, M., and D. Restuccia, "The productivity of nations," Economic Quarterly - Federal Reserve Bank of Richmond, vol. 92, no. 3, pp. 195-223, 2006. 
42.Duarte, M., and D. Restuccia, "The role of the structural transformation in aggregate productivity," Quarterly Journal of Economics, vol. 125, no. 1, pp. 129-173, 2010.

43.Dunn, E., and M. Norton, Happy money: The science of happier spending. Simon \& Shuster, 2013.

44.Easterlin, R." Does economic growth improve the human lot? Some empirical evidence," in P. David and M. Reder (Ed.), Nations and households in economic growth: Essays in honor of Moses Abramowitz, Academic Press, 2014, pp. 89-125.

45.Easterlin, R. "Happiness, growth, and public policy. Economic Inquiry," vol. 51, no. 1, pp. 1-15, 2013.

46.Economist Intelligence Unit. Long-term macroeconomic forecasts: Key trends to 2050. 2015.

Available: http://www.eiu.com/public/topical_report.aspx?campaignid=ForecastingTo2050

47.Eichengreen, B. "Secular stagnation: The long view," American Economic Review, vol. 105, no. 5, pp. 66-70, 2015.

48.Feenstra, R., R. Inklaar, and M. Timmer, "The next generation of the Penn World Table," American Economic Review, vol. 105, no. 10, pp. 3150-3182, 2015.

49.Field, A. Discovering statistics using SPSS (3rd Ed.). Sage Publications, 2009.

50.Field, F. "U.S. economic growth in the gilded age," Journal of Macroeconomics, vol. 31, pp. 173-190, 2007.

51.Frey, B., and A. Stutzer, "Happiness, economy and institutions," Economic Journal, vol. 110, no. 466, pp. 918938, 2000.

52.Frey, B., and A. Stutzer, "What can economists learn from happiness research?," Journal of Economic Literature, vol. 40, no. 2, pp. 402-435, 2002.

53.Fry, R. Millennials surpass Gen Xers as the largest generation in U.S. labor force. 2015. Available: http://www.pewresearch.org/fact-tank/2015/05/11/millennials-surpass-gen-xers-as-the-largest-generation-in-u-slabor-force/

54.Gallup. Economic Confidence Index. 2016a. Available: http://www.gallup.com/poll/183095/economic-confidenceindex-rebounds.aspx?utm_source=Economy\&utm_medium=newsfeed\&utm_campaign=tiles

55.Gallup. How does the Wells Fargo/Gallup Investor and Retirement Optimism Index work? 2016b. Available: http://www.gallup.com/177557/wells-fargo-gallup-investor-retirement-optimism-index-methodology.aspx.

56.Gallup-Healthways. Gallup-Healthways well-being index. 2015. Available: http://www.well-beingindex.com/

57.Galson, W., and E. Kamarck, Overcoming corporate short-termism: Blackrock's chairman weighs in. 2015. Available: http://www.brookings.edu/blogs/fixgov/posts/2015/04/17-fink-buybacks-corporate-short-termismgalston-kamarck?utm_campaign=Brookings+Brief\&utm_source=hs_email\&utm_medium=email\&utm_content $=17171270 \& \_$hsenc=p2ANqtz-9USAzw43h6K8hlL_7Ll48HPXsW_II8NGK2AIYs8k5LrIzdpnfqsxbX7OnNbtdekC 4WT0YqPuuejvQeurSvRZYjZGDMeA\&_hsmi=17171270

58.Geletkanycz, M., "The salience of cultural consequences: The effects of cultural values on top executive commitment to the status quo," Strategic Management Journal, vol. 18, no. 8, pp. 615-634, 1997.

59.Gordon, R., Is the U.S. economic growth over? Faltering innovation confronts the six headwinds. NBER working paper 18315. 2012. Available:

http://faculty-web.at.northwestern.edu/economics/gordon/is\%20us\%20economic\%20growth\%20over.pdf

60.Gordon, R., "Secular stagnation: A supply-side view," American Economic Review, vol. 105, no. 5, pp. 54-59, 2015.

61.Gordon, R., "Perspectives on the rise and fall of American growth," American Economic Review, vol. 106, no. 5, pp. 72-76, 2016.

62.Goodhart, C., and P. Erfurth, Demography and economics: Look past the past. 2014.

Available: http://www.voxeu.org/article/demography-and-economics-look-past-past

63.Goodridge, P., J. Haskel, and G. Wallis, "Can intangible investment explain the UK productivity puzzle?," National Institute economic review, vol. 226, no. 1, pp. 42-49, 2013.

64.Graetz, G., and G. Michaels, Robots at work. Center for Economic Performance at the London School of Economics and Political Science. 2015. Available: http://cep.lse.ac.uk/pubs/download/dp1335.pdf

65.Graham, C., "Insights on development from the economics of happiness," World Bank Research Observer, vol. 20, no. 2, pp. 201-231, 2005.

66.Griffiths, W., C. Hill, and G. Judge, Learning and practicing econometrics. John Wiley \& Sons, Inc., 1993.

67.Griliches, Z., "Productivity puzzles and R\&D: Another nonexplanation," The Journal of Economic Perspectives (1986-1998), vol. 2, no. 4, pp. 9-21, 1988. 
68.Guiso, L., P. Sapienza, and L. Zingales, "Corporate culture, societal culture, and institutions," American Economic Review, vol. 105, no. 5, pp. 336-339, 2015.

69.Haines, J., and N. Sharif, "A framework for managing the sophistication of the components of technology for global competition," Competitiveness Review, vol. 16, no. 2, pp. 106-121, 2006.

70.Hall, R., and C. Jones, "Why do some countries produce so much more output per worker than others?," Quarterly Journal of Economics, vol. 114, no. 1, pp. 83-116, 1999.

71.Hansen, A. "Economic progress and declining population growth.," American Economic Review, vol. 29, no. 1, pp. 1-15, 1939.

72.Harrod, R., "An essay in dynamic theory," The Economic Journal, vol. 49, no. 193, pp. 14-33, 1939.

73.Helliwell, J., R. Layard, and J. Sachs, World happiness report. 2012. Available: http://www.earth.columbia.edu/ sitefiles/file/Sachs\%20Writing/2012/World\%20Happiness\%20Report.pdf

74.Helliwell, J., and R. Putnam, "The social context of well-being," The Philosophical Transactions of the Royal Society, vol. 359, pp. 1435-1446, 2004.

75.Hofstede, G., "Culture and organizations," International Studies of Management and Organization, vol. 10, no. 4, pp. 15-41, 1981.

76.Hofstede G., "The cultural relativity of the quality of life concept," Academy of Management Review, vol. 9, no. 3, pp. 389-398, 1984.

77.Hofstede, G., "The business of international business is culture," International Business Review, vol. 3, no.1, pp. 1-14, 1994.

78.Hofstede, G., "Attitudes, values and organizational culture: Disentangling the concepts," Organization Studies, vol. 19, no. 3, pp. 477-493, 1998a.

79.Hofstede, G., "Think locally, act globally: Cultural constraints in personnel management," Management International Review, vol. 38, no. 2, pp. 7-26, 1998b.

80.Hofstede, G., Culture's consequences. Sage Publications, 2001.

81.Hofstede, G., "Business goals for a new world order: beyond growth, greed and quarterly results," Asia Pacific Business Review, vol. 15, no. 4, pp. 481-488, 2009.

82.Hofstede, G., and M. Bond, "The Confucius connection: From cultural roots to economic growth," Organizational Dynamics, vol. 16, no. 4, pp. 5-21, 1988.

83.Hofstede, G., and G. Hofstede, Dimension data matrix. n.d.

Available: http://www.geerthofstede.nl/dimension-data-matrix

84.Hofstede, G., and M. Minkov, "Long- versus short-term orientation: New perspectives" Asia Pacific Business Review, vol. 16, no. 4, pp. 493-504, 2010.

85.Holtz-Eakin, D., "Solow and the states: Capital accumulation, productivity, and economic growth," National Tax Journal, vol. 46, no. 4, pp. 425-439, 1993.

86.Inklaar, R., M. Timmer, and B. Van Ark, "Data for productivity measurement in market services: An international comparison," International Productivity Monitor, vol. 16, pp. 71-81, 2007.

87.International Monetary Fund. World economic outlook database, October 2005 edition. 2015.

Available: http://www.imf.org/external/pubs/ft/weo/2015/02/weodata/index.aspx

88.Judge, T., and J. Kammeyer-Mueller, "Happiness as a societal value," Academy of Management Perspectives, vol. 25, no. 1, pp. 30-41, 2011.

89.Kahneman, D., and A. Krueger, "Developments in the measurement of subjective well-being," The Journal of Economic Perspectives, vol. 20, no. 1, pp. 3-24, 2006

90.Katona, G., "Psychology and consumer economics," Journal of Consumer Research, vol. 1, no. 1, pp. 1-8, 1974.

91.Kogel, T., "Youth dependency and total factor productivity," Journal of Development Economics, vol. 76, no. 1, pp. 147-173, 2005.

92.Krugman, P., The age of diminished expectations. The MIT Press, 1997.

93.Lagarde, C., Lift growth today, tomorrow, together. 2015.

Available: http://www.imf.org/external/np/speeches/2015/040915.htm

94.Lenartowicz, T., and K. Roth, "A framework for culture assessment," Journal of International Business Studies, vol. 30, no. 4, pp. 781-798, 1999.

95.Lyubomirsky, S., and H. Lepper, "A measure of subjective happiness: Preliminary reliability and construct validation" Social Indicators Research, vol. 46, no. 2, pp. 137-155, 1999. 
96. MacKerron, G., "Happiness economics from 35000 feet," Journal of Economic Surveys, vol. 26, no. 4, pp. 705$735,2012$.

97.Maddison, A., The world economy: A millennial perspective. OECD, 2001.

98.Mankiw, G., D. Romer, D., and D. Weil, "A contribution to the empirics of economic growth," Quarterly Journal of Economics, vol. 107, no. 2, pp. 407-437, 1992.

99.Manyika, J., J. Woetzel, and J. Remes, "A productivity perspective on the future of growth," McKinsey Quarterly, vol. 3, pp. 136-146, 2014.

100.Maslow, A., "A theory of human motivation," Psychological Review, vol. 50, no. 4, pp. 370-396, 1943.

101.Merriam-Webster's collegiate dictionary (11th ed.). Globalization. Merriam-Webster, 2012a.

102.Merriam-Webster's collegiate dictionary (11th ed.). Economy. Merriam-Webster, 2012b.

103.National Archives. U.S. Declaration of Independence. n.d.

Available: http://www.archives.gov/exhibits/charters/declaration_transcript.html

104.National Association of Home Builders. Builder confidence hits highest level since November 2005, 2016.

Available: http://www.nahb.org/news_details.aspx?newsID=16899

105.National Bureau of Economic Research. Business cycle dating committee. 2010.

Available: http://www.nber.org/cycles/sept2010.html

106. National Federation of Independent Business. NFIB Small Business Optimism Index. 2016.

Available: http://www.nfib.com/surveys/small-business-economic-trends/

107.Nobel Prize. Prizes and laureates in economic sciences. 2016.

Available: http://www.nobelprize.org/nobel_prizes/economic-sciences/laureates/

108.Nolan, P., "Solving the productivity puzzle," Public Finance, vol. 6, pp. 34-37, 2014.

109.Nyce, S. "The aging workforce: Is demography destiny?," Generations, vol. 31, no. 1, pp. 9-15, 2007.

110.O'Clock, P. and K. Devine, "The role of strategy and culture in the performance evaluation of international strategic business units," Management Accounting Quarterly, vol. 4, no. 2, pp. 18-26, 2003.

111.Ohlin, B. (1957). Interregional and international trade. Cambridge, MA: Harvard University Press.

112.Oishi, S., M. Koo, and S. Akimoto, "Culture, interpersonal perceptions, and happiness in social interactions.

Personality and Social Psychology Bulletin, vol. 34, no. 3, pp. 307-320, 2008.

113.Oishi, S. and U. Schimmack, "Culture and well-being: A new inquiry into the psychological wealth of nations,"

Perspectives on Psychological Science, vol. 5, no. 4, pp. 463-471, 2010.

114.Organization for Economic Co-operation and Development. OECD Compendium of Productivity Indicators 2013. OECD Publishing, 2013.

115. Organization for Economic Co-operation and Development. Productivity statistics. 2015.

Available: http://www.oecd.org/std/productivity-stats/

116.Organization for Economic Co-operation and Development. Policymakers: Act now to keep promises! $2016 \mathrm{a}$.

Available: http://www.oecd.org/eco/outlook/OECD-Economic-Outlook-June-2016-handout.pdf

117. Organization for Economic Co-operation and Development. OECD. Stat. 2016b.

Available: http://stats.oecd.org/Index.aspx?DataSetCode\%3DANHRS

118. Organization for Economic Co-operation and Development. Glossary. 2016c.

Available: http://stats.oecd.org/glossary/index.htm

119. Oswald, A., "Happiness and economic performance," Economic Journal, vol. 107, no. 445, pp. 1815-1831, 1997.

120.Oswald, A., "Emotional prosperity and the Stiglitz Commission," British Journal of Industrial Relations, vol. 48, no. 4, pp. 651-669, 2010.

121.Oswald, A., E. Proto, and D. Sgroi, Happiness and productivity. IZA Discussion Paper No. 4645, Germany, 2009. Available: http://papers.ssrn.com/sol3/papers.cfm?abstract_id=1526075

122.Ovaska, T., and R. Takashima, "Does a rising tide lift all the boats? Explaining the national inequality of happiness," Journal of Economic Issues, vol. 44, no. 1, pp. 205-223, 2010.

123.PNC Financial. Economic outlook survey: Survey of small and middle-market business owners. 2016.

Available: https://www.pnc.com/en/about-pnc/media/press-kits/economic-outlook-survey.html

124.Porter, M., "The competitive advantage of nations," Harvard Business Review, vol. 68, no. 2, pp. 73-93, 1990.

125.Porter, M., S. Stern, and M. Green, Social progress index: Executive summary. 2014. Available: http://www.socialprogressimperative.org/system/resources/W1siZiIsIjIwMTQvMDQvMTUvMTQvMjQvNTcvMj 
Q3L1NvY2lhbF9Qcm9ncmVzc19JbmRleF8yMDE0X0V4ZWN1dGl2ZV9TdW1tYXJ5LnBkZiJdXQ/Social\%20Pro gress\%20Index\%202014\%20Executive\%20Summary.pdf

126.Powdthavee, N., "How much does money really matter? Estimating the causal effects of income on happiness," Empirical Economics, vol. 39, no. 1, pp. 77-92, 2010.

127.Pressey, A., and H. Selassie, "Are cultural differences overrated? Examining the influence of national culture on international buyer-seller relationships," Journal of Consumer Behaviour, vol. 2, no. 4, p. 354, 2003.

128.Ricardo, D., On the principles of political economy and taxation. ElecBook. 1891. Available: https://books.google.com/books?hl=en\&lr=\&id=_Qg-AAAAYAAJ\&oi=fnd\&pg=PA5\&dq=Ricardo,+ D.$+\%$ $282001 \% 29+[1821] .+$ On + the + principles + of + political+economy + and +taxation. + ElecBook\&ots=osmyaOsYkD\& sig=QTjM03QJXfoE7Z55zSAnsSzYiEM\#v=onepage\&q\&f=false (Original work published 1817)

129.Ross, C., and A. Murray, "Aggregate measures of income and output in Canada and the United States: Implications for productivity and living standards," International Productivity Monitor, vol. 19, pp. 20-39, 2010.

130.Sargent, J., "The UK productivity puzzle - or is it?," Economic Affairs, vol. 33, no. 2, pp. 257-262, 2013.

131.Siegel, J., "Is productivity plunging?," Kiplinger's Personal Finance.

Available: http://www.kiplinger.com/article/business/T019-C019-S002-is-productivity-plunging.html

132.Sly, N., "International productivity differences, trade and the distributions of factor endowments," Review of International Economics, vol. 20, no. 4, pp. 740-757, 2012.

133.Smith, A., "An inquiry into the nature and causes of the wealth of nations. ElecBook. 2001. Available: http://site.ebrary.com.library.capella.edu/lib/capella/detail.action?docID=2001574\# (Original work published 1776)

134.Smith, J., "International productivity comparisons: An examination of data sources. International Productivity Monitor, vol. 6, no. 6, pp. 64-71, 2003.

135.Solow, R., "A contribution to the theory of economic growth," Quarterly Journal of Economics, vol. 70, no. 1, pp. 65-94, 1956.

136.Solow, R., "Technical change and the aggregate production function," The Review of Economics and Statistics, vol. 39, no. 3, pp. 312-320, 1957.

137.Sondergaard, M., "Research Note: Hofstede's Consequences: A study of reviews, citations and replications," Organization Studies (Walter De Gruyter Gmbh \& Co. KG.), vol. 15, no. 3, pp. 447-456, 1994.

138.Stiglitz, J., A. Sen, and J.P. Fitoussi, Report by the Commission on the Measurement of Economic Performance and Social Progress. 2009. Available: http://www.stiglitzsen-fitoussi.fr/documents/rapport_anglais.pdf

139.Swanson, R. A., and E. F. Holton, Research in organizations: Foundations and methods of inquiry. BerrettKoehler, 2005 (Eds.).

140.Syverson, C., "What determines productivity?," Journal of Economic Literature, vol. 49, no. 2, pp. 326-365, 2011.

141.Triandis, H., "The many dimensions of culture," Academy of Management Executive, vol. 18, no. 1, pp. 88-93, 2004.

142.Triplett, J., "The Solow productivity paradox: What do computers do to productivity?," Canadian Journal of Economics, vol. 32, no. 2, pp. 309-334, 1999.

143.United Nations. World population prospects. 2015. Available: https://esa.un.org/unpd/wpp/

144.United Nations. The United Nations Statistics Division: The System of National Accounts 2008. 2016a.

Available: http://unstats.un.org/unsd/nationalaccount/sna2008.asp

145.United Nations. International Day of Happiness. 2016b.

Available: http://www.un.org/en/events/happinessday/

146.United Nations. The International Telecommunication Union: Statistics. 2016c.

Available: http://www.itu.int/en/ITU-D/Statistics/Pages/stat/default.aspx

147.University of Michigan. Surveys of consumers. 2016. Available: http://www.sca.isr.umich.edu/

148.van Ark, B., "International productivity" in Ashish K. Vaidya (eds.), Globalization: Encyclopedia of trade, labor, and politics. 2005. Available: http://library.capella.edu/login?url=http://search.credoreference.com.library. capella.edu/content/entry/abcgetlp/international_productivity/0

149.van Ark. B., and R. McGuckin, "International comparisons of labor productivity and per capita income," Monthly Labor Review, vol. 122, no. 7, pp. 33-41, 1999. 
150.Van Boven, L., and T. Gilovich, "To do or to have? That is the question," Journal of Personality and Social Psychology, vol. 85, no. 6, pp. 1193-1202, 2003.

151.Veenhoven, R., Conditions of happiness. D. Reidel Publishing Company, 1984.

152.Veenhoven, R., "Return of inequality in modern society? Test by dispersion of life-satisfaction across time and nations," Journal of Happiness Studies, vol. 6, no. 4, pp. 457-487, 2005.

153.Veenhoven, R., "Greater happiness for a greater number: Is that possible or desirable?," Journal of Happiness Studies, vol. 11, no. 5, pp. 605-629, 2010.

154.Vogt, P., Quantitative research methods for professionals. Allyn \& Bacon, 2007.

155.Wallis, C., Science of happiness: New research on mood. Time. 2005.

Available: http://content.time.com/time/printout/0,8816,1015902,00.html

156.Weimann, J., A. Knabe, and R. Schob, Measuring happiness: The economics of well-being. The MIT Press, 2015.

157.Weller, C., and J. Odum, Economic snapshot: June 2015. 2015.

Available: https://cdn.americanprogress.org/wp-content/uploads/2015/06/EconSnap_June15.pdf

158.Wolf, M., Why globalization works. Yale University Press, 2004

159.World Trade Organization. International trade statistics 2014. 2015.

Available https://www.wto.org/english/res_e/statis_e/its2014_e/its14_toc_e.htm

160.World Values Survey. Online data analysis. n.d. Available: http://www.worldvaluessurvey.org/WVSOnline.jsp

161.Yucel, R., H. Elibol, and O. Dagdelen, "Globalization and international marketing ethics problems," International Research Journal of Finance \& Economics, no. 26, pp. 93-104, 2009. 


\section{APPENDIX A}

Table A1. Statistical results summary

\begin{tabular}{|c|c|c|c|c|c|c|c|c|c|c|}
\hline \multirow[b]{2}{*}{$\begin{array}{l}\text { Hypothesis } \\
\text { Designation }\end{array}$} & \multirow[b]{2}{*}{ Constant } & \multicolumn{6}{|c|}{ Independent Variable } & \multirow[b]{2}{*}{$F$} & \multirow[b]{2}{*}{ Adj. $\mathrm{R}^{2}$} & \multirow[b]{2}{*}{$\begin{array}{c}\mathrm{n} \\
\text { (sample } \\
\text { size) }\end{array}$} \\
\hline & & Happiness & IDV & PDI & MAS & UAI & LTO & & & \\
\hline $\mathrm{H}_{0}$ & 1567.70 & 9926.85 & 375.31 & -333.98 & -117.58 & $-360.01^{*}$ & $455.51^{* *}$ & $3.32^{* *}$ & 0.30 & 33 \\
\hline $\mathrm{H}_{01}$ & -48642.41 & $15160.85^{* *}$ & & & & & & $6.08^{* *}$ & 0.09 & 54 \\
\hline $\mathrm{H}_{02}$ & $61965.77^{* * *}$ & & $485.37^{* *}$ & $-424.43^{* *}$ & -9.45 & -108.280 & $261.65^{*}$ & $8.05^{* * *}$ & 0.37 & 62 \\
\hline $\mathrm{H}_{02 \mathrm{a}}$ & $109972.77^{* * *}$ & & & $-776.66^{* * *}$ & & & & $23.78^{* * *}$ & 0.27 & 62 \\
\hline $\mathrm{H}_{02 \mathrm{~b}}$ & $83723.45^{* * *}$ & & & & & -282.46 & & 2.62 & 0.03 & 62 \\
\hline $\mathrm{H}_{02 \mathrm{c}}$ & $29718.72^{* * *}$ & & $767.80^{* * *}$ & & & & & $30.06^{* * *}$ & 0.32 & 62 \\
\hline $\mathrm{H}_{02 \mathrm{~d}}$ & $68103.21^{* * *}$ & & & & -66.07 & & & 0.11 & 0.02 & 62 \\
\hline $\mathrm{H}_{02 \mathrm{e}}$ & $51682.30^{* * *}$ & & & & & & 265.24 & 2.25 & 0.02 & 62 \\
\hline $\mathrm{H}_{03}$ & -76024.85 & 11931.66 & $614.057^{* * *}$ & & & & $528.94^{* *}$ & $4.82^{* * *}$ & 0.26 & 62 \\
\hline $\mathrm{H}_{04}$ & $63615.50^{* * *}$ & & $532.77^{* * *}$ & $-398.43^{* *}$ & & & & $17.87^{* * *}$ & 0.36 & 62 \\
\hline
\end{tabular}

Dependent variable: Productivity.

Significance is denoted by ${ }^{*},{ }^{* *},{ }^{* * *}$ for $10 \%, 5 \%$, and $1 \%$ levels, respectively.

Consequently, as per the above-specified general equation formulation (2), the estimated coefficients for the (sub)hypotheses result in the following productivity equations:

$\mathrm{H}_{0}: \mathrm{p}=1567.70+9926.85$ Happiness $-333.98 \mathrm{PDI}+375.31 \mathrm{IDV}-117.58 \mathrm{MAS}-360.01 \mathrm{UAI}+$ 455.51LTO

$\mathrm{H}_{01}: \mathrm{p}=-48642.41+15160.85$ Happiness

$\mathrm{H}_{02}: \mathrm{p}=61965.77-424.43 \mathrm{PDI}+485.37 \mathrm{IDV}-9.45 \mathrm{MAS}-108.28 \mathrm{UAI}+261.65 \mathrm{LTO}$

$\mathrm{H}_{02 \mathrm{a}}: \mathrm{p}=109972.77-776.66 \mathrm{PDI}$

$\mathrm{H}_{02 \mathrm{~b}}: \mathrm{p}=83723.45-282.46 \mathrm{UIA}$

$\mathrm{H}_{02 \mathrm{c}}: \mathrm{p}=29718.72+767.80 \mathrm{IDV}$

$\mathrm{H}_{02 \mathrm{~d}}: \mathrm{p}=68103.21-66.07 \mathrm{MAS}$

$\mathrm{H}_{02 \mathrm{e}}: \mathrm{p}=51682.30+265.24 \mathrm{LTO}$

$\mathrm{H}_{03}: \mathrm{p}=-76024.85+11931.66$ Happiness $+614.06 \mathrm{IDV}+528.94 \mathrm{LTO}$

$\mathrm{H}_{04}: \mathrm{p}=63615.50-398.43 \mathrm{PDI}+532.77 \mathrm{IDV}$ 